\title{
ANIMALS, DE ANIMA, OBJET (PETIT) A, AND THE ANTHROPOCENE
}

\section{David Green}

\begin{abstract}
There is every indication that the first men were closer than we are to the animal world; they distinguished the animal from themselves perhaps, but not without a feeling of doubt mixed with terror and longing.
\end{abstract}

\section{George Bataille'}

During my MFA study I looked at research material describing neural processes associated with visual perception. There are certain objects and dynamics in our immediate environment that we've evolved to analyse instantly and precisely using an impressive neural armoury. Our adaptive sensitivities make sense; we recognise both animal and human body movement in the environment with very little to go on. Our considerable neural investments include recognising faces and reading facial expressions, which are critical survival skills for knowing when to crawl away or when to run. According to neuroscientist Eric Kandel, "the human brain devotes more area to face recognition than to the recognition of any other visual object."2

Now working on a practice-led $\mathrm{PhD}, \mathrm{I}$ continue to experiment with images that work to perceptual acuities of the brain. It may come as no surprise that these same subject matters are the perennial focus of cinema. Arguably, the cinema never transfixes us more than when it is focused on human and animal motion and behaviour.

In my art practice, after filming or appropriating digital video in order to model a problem or dynamic that piques my curiosity, I go through the footage and experiment by stripping away detail or by using image against image to occlude detail, bringing it just to the verge of perceptibility. Footage abstracted in this way is generally more readable by motion than by form. I call this methodology "disarticulated cinema." It is a contrasting strategy to traditional cinematic structure. Rather than feed information out in strategic doses from a single screen, I fragment and redistribute evidence around a navigable space for consideration by the viewer. I invite the viewer to use their own memory and imagination to activate meaning in order to fill the gaps between fragments of evidence.

In 2017 I experimented with a colonial-era African animal exploitation film that became the basis of an installation I called Emergence. Working with images of imposed human-animal interactions and animal herd behaviours prompted a cascade of questions and thoughts in my mind. I described the installation in detail in an earlier Scope artists page by the same title. ${ }^{3}$ This writing picks up and extends certain thoughts from that article as they concern our uneasy relationships with wild animals.

Even though the vision of a galloping antelope may feel cohesive to the observer, we now know that the retinal information is actually broken up into fragments for neural analysis, subject to "parallel distributed processing" (or PDP) in the visual cortex and then linked to other neural networks for further analysis. Object edge, colour field, direction of movement, and object growth are analysed in separate processes and streamed in forward motion through a variety of neural channels. ${ }^{4}$ So far, no one has located a specific process that is responsible for reuniting fragmented components or even synchronising them. We perceive a cohesive animal in full flight, but that animal, 
like consciousness, may never actually be stitched together at any particular moment in time or in any single location in the brain. In fact, this conundrum, called "the binding problem", could turn out to be neurologically unlocatable. Perhaps it is an emergent phenomenon resulting from PDP signal spillage, or something equally recondite that Stephen Jay Gould and Elisabeth Vrba would describe as an "exaptation."

Disarticulated artworks are intended primarily as propositional objects; video installations can prompt questions and actuate thinking. Deconstructing and experimenting with the film from colonial Africa prompted a number of questions for me: How would early man receive the visual experience of migrating herds in the distance without a ubiquitous and easily transferable visual culture or a history of art to call upon? What manner of desire compelled our forebears to drag these neurally held images, reproducing them sometimes kilometres deep in a cave? Above all, how could our utterly conjoined existence with fellow animals devolve so disastrously as to bring us to where are now, at the tipping point of the Anthropocene? This article meanders along my questions and speculations regarding our conflicted relationships with other animals.

\section{CAPTURING ANIMALS}

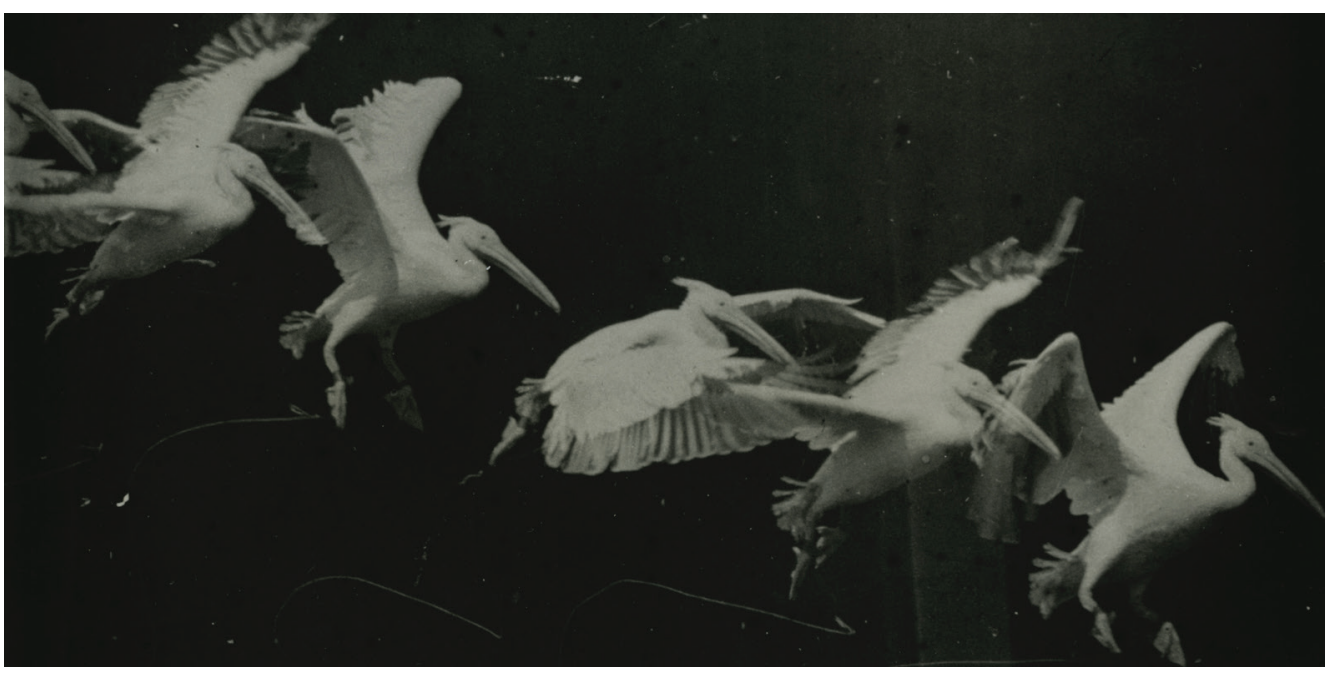

Figure I. A multiple exposure photo of flying pelican taken by Étienne-Jules Marey circa I 882. https://upload.wikimedia.org/wikipedia/commons/e/eO/Marey___birds.jpg

Animals are well and truly entangled in the advent of early cinema. Animal locomotion was the primary obsession behind many of the earliest applications of still photography for the purpose of time-based recording. The problemsolving techniques invented by 19th century experimental photographers such as Marey, Anschütz, and Muybridge were seminal contributions to the birth of cinema. Their discoveries helped accelerate development of a nascent motion-picture technology, which would pave the way for the global industry that exploded in its wake. One could say that our obsessive-compulsive fixation with animals has a long history of bringing about conceptual revolutions.

The word 'animal' comes to us from the Latin word "anima", or breath, a symptom of oxygen exchange, and an important detail in describing the various signs and symptoms associated with being a multicellular creature in the world. "Anima" is also the Latin word for soul. However, the concept of soul has held different meanings in different times and places. 
In his work translated from Greek to Latin as, De Anima, or in English, "On the Soul," Aristotle uses the concept of soul as a kind of black box to describe the mysteries around a living body's attributes of perception, behaviour, and growth. These include the calculating, actioning, growing, dying, and energy seeking mechanisms of self-determining bodies that move intentionally to satisfy the needs and desires associated with being alive. ${ }^{6}$ The autonomous bodies with soul that Aristotle describes include all those that, by observation, share the basic qualities of responsiveness to stimuli and spontaneous decision making in the world. This includes all living animals of every scale - not only humans, mammals, or vertebrates - all. Movement is at the centre of many debates intent on defining how this "black box" works and exactly what it does. For Aristotle the soul is the origin or cause of the animal's motion. For Aristotle, plants too had this living attribute, but they were inverted, with their mouths in the soil and their genitals in the air.

For contemporaneous philosophers who argued this conceptual construct, the idea of "the soul" was an epistemic object (or thinking tool) that had at its heart the question: "What is it to be alive?" For Aristotle, it was anything that seeks nourishment, grows, and declines - but only while it actively does. This ineffable quality, or its lack, is the difference between a dead body and a live one - which for him did not mean that when this dynamic leaves a body it continues to exist somewhere else, just that the soul is no longer to be found there.

The idea of the soul, of course, is at the heart of much of religious thought in countless permutations, but from the anthropocentric revolution at the heart of the Enlightenment, as soon as the Cartesian apartheid split the human organism into body and soul, we began to break earth on the superhighway to the Great Acceleration. The other animals paid first and most dearly when they lost their souls and transformed into mere mechanisms in the eyes of Western culture.

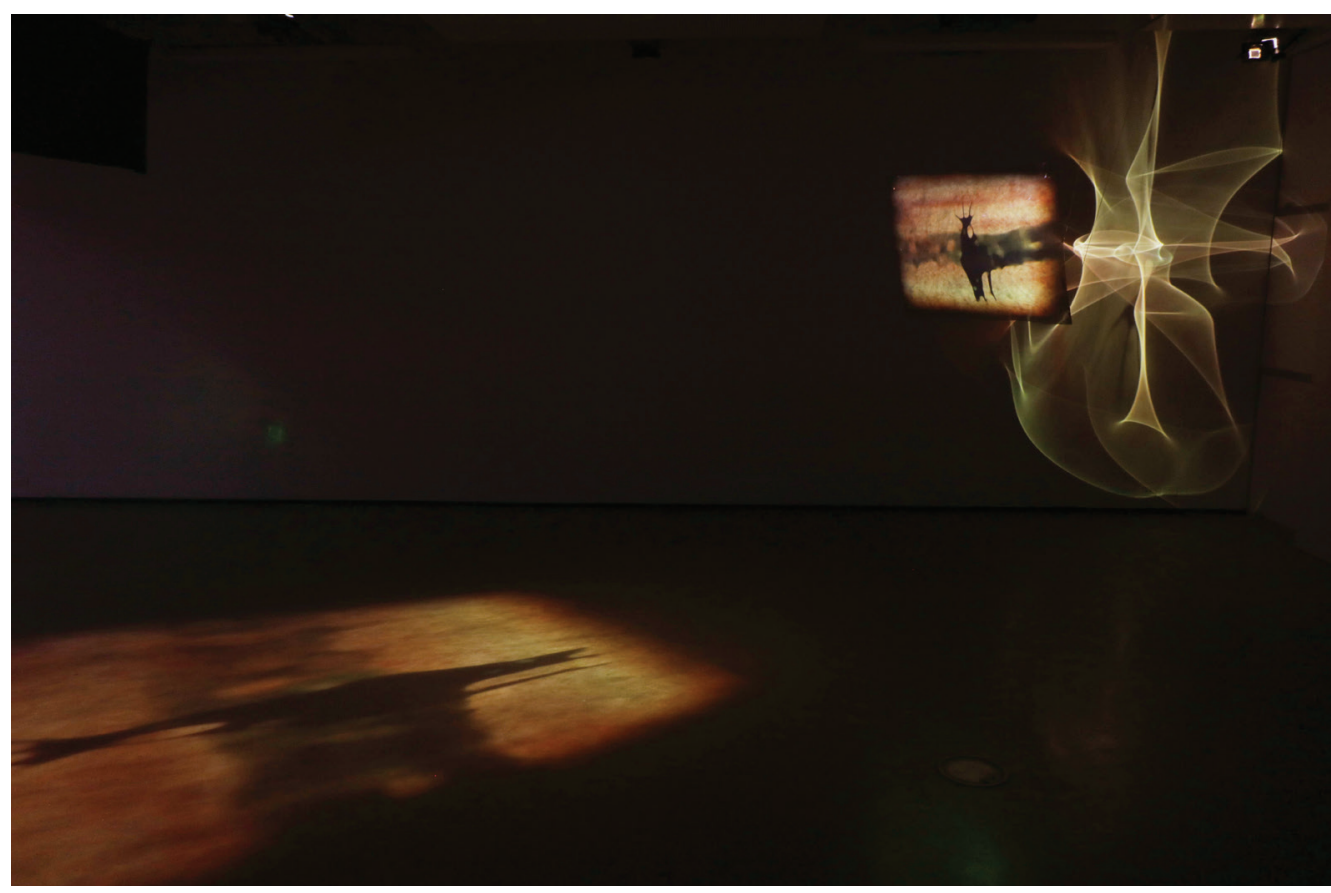

Figure 2. David Green, Emergence, 2017, partial view video projection installation, Dunedin School of Art Gallery. Photograph: Mark Bolland. 
From cave paintings to contemporary robotics, we strain to mitigate our desires arising from the many enviable qualities that other animals enjoy. Perhaps from the first moment of sentience, our subspecies coveted the remarkable attributes, abilities, and agilities of our fellow terrestrials.

As I paired back images from the ninety-year-old, compressed, and otherwise degraded film footage captured in colonial Rhodesia, now Zimbabwe, I was reminded of the images captured in Werner Herzog's film shot in the Chauvet Caves. ${ }^{7}$

\section{PARIETAL ART}

Many scholars have weighed in on the 45,000 or so year-old markings discovered deep within cave systems in diverse corners of the world. Anyone can guess what might have been going on in the minds of the mark-makers - and many have. There are countless theories published over the last century: individual theories, collections of supporting theories, and varietal recapitulations containing the most compelling theories. Some believe that cave drawing began spontaneously, when first man became a competent hunter, felt sated, secure, and comfortable enough to enjoy a little leisure time, which resulted

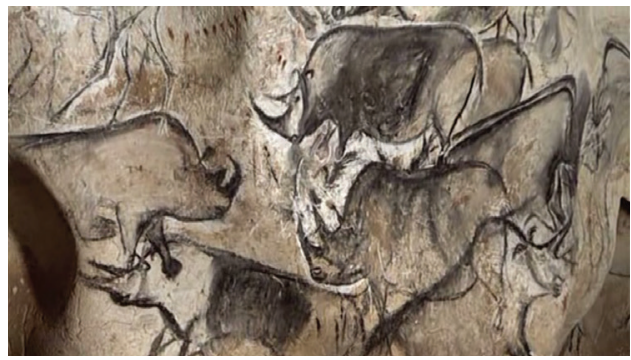

Figure 3. Chauvet Cave drawings of rhinoceros. Screenshot from Werner Herzog's film Cave of Forgotten Dreams. ${ }^{8}$ in an outbreak of "art for art's sake." Other scholars

have questioned this, asking why the featured animals are always of the awe inspiring variety — where are the cute mice and decorative insects? Some think image-making automatically arose with higher order consciousness, as an evolved concept of self, associated with the ability to construct a past and project possible futures. Others are convinced that the markings are simply chalkboard lessons in how to identify and kill optimum prey species while remaining alert to their associated predators. Still others believe the impetus was more spiritual, more mystical, perhaps the animal images were made as aspirational self-portraiture, a claiming of totemic relation with the most awesome and powerful of the others sharing life on the savannah.

On a meta-level, I wonder if the emergent ability to conceptually separate ourselves from the fabric of life through these and other lines of demarcation, as no fellow creature could before, ${ }^{9}$ marked the beginning of the end of our subspecies' first and final epoch: the Anthropocene.

\section{UNTAMED}

Animals came from over the horizon. They belonged there and here. Likewise they were mortal and immortal. An animal's blood flowed like human blood, but its species was undying and each lion was Lion, each ox was Ox. This — maybe the first existential dualism — was reflected in the treatment of animals. They were subjected and worshipped, bred and sacrificed.

John Berger ${ }^{10}$

In his book, Animals in Film"', Jonathan Burt notes that in modernity, animals captured in still and motion pictures help us construct a soothing virtual impression that we still share their world. We manage to feel this even as we increasingly supplant them in order to feed our exploding populations. Burt comments on Bill Viola's 1986 Film, I Do 
Not Know What It Is I Am Like'2, writing that the wild animal exterior is presented as the frontier that can never be crossed (even as we dolly in, slowly, wistfully, until we are close enough to see our own technological manifestation reflected in their full screen eye). We bear down on them. We know they can see us. Yet, they are inscrutable; we cannot know what they make of us, or what it is like to be them. Noting that wild animals never welcome our attention, Burt describes John Huston's film version of Moby Dick ${ }^{13}$ as an example of a narrative built entirely around an intimate relationship between a man and an animal. Despite the complex anthropomorphic intentions and emotions projected onto a single white whale by the bitter Ahab, their on-film relationship can only play out as a collision of surfaces.

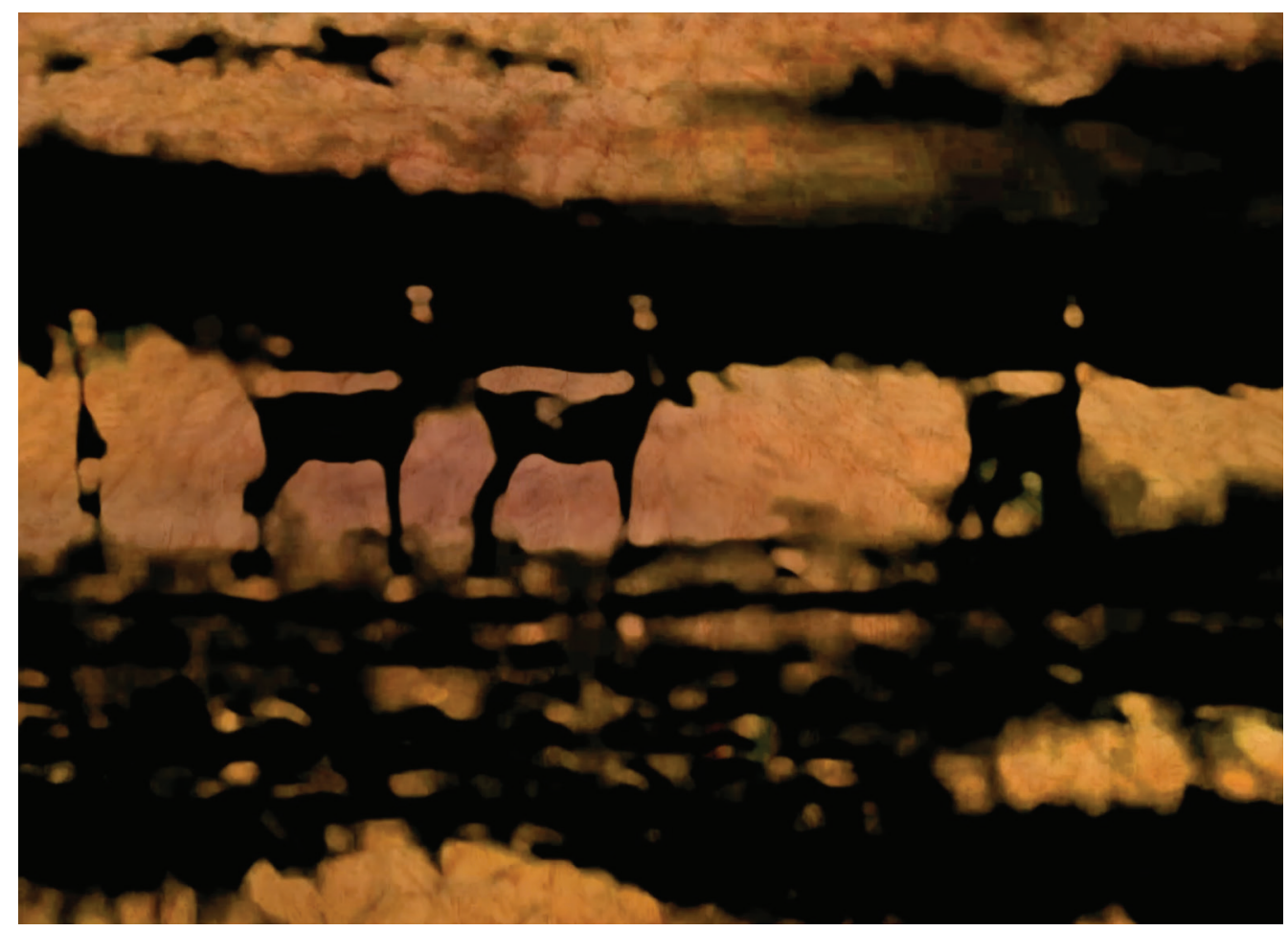

Figure 4. David Green, Frame from 'Parietal', 2017, a single channel video, from the video installation, Emergence.

The feature film I appropriated was called Untamed Africa. ${ }^{14}$ It had been cobbled together in the early 1930s from footage gathered by a U.S. born "entrepreneur" named Wynant Hubbard. The film is disturbing, documenting a nadir of cultural and animal collisions during the colonial era. Hubbard's gleeful documentations leave a toxic record of cultural and zoological catastrophes.

According to Daniel Bender in the book, The Animal Game ${ }^{15}$, after gaining an undergraduate degree in geology from Harvard University, Hubbard moved his young family to South Africa on the promise of a management position in an asbestos mine. Luckily for the local inhabitants, the business went bankrupt as the family was in transit. Unluckily Hubbard wasn't a quitter, so he undertook to redeem the bad move with the notion of trapping African fauna to sell to zoological parks, while adding to his income by trafficking in used animal parts (e.g. tusks, horns, and pelts). In the very midst of these misadventures, Hubbard found time to write a self-promotional book whose title completes the picture: Wild Animals: A White Man's Conquest of Jungle Beasts. He also arranged to have himself and his young family filmed while engaging in their day-to-day delinquencies. Among Hubbard's nefarious gifts was 
inventing "natural history" filming techniques; he slapped together small but secure, set-dressed enclosures, where he would pit ruminants or scavengers against pre-starved predators as the camera rolled. On other occasions he would have his cameraman train the camera on peacefully grazing herds in the veld, and then suddenly fire a volley of bullets offscreen so frightened animals would panic and scatter for viewers at home. Between long idyllic pans over galloping all-sorts, his shot list would read like a litany of criminal acts to contemporary sensibilities. But in the late 1920s, his little films had a first life as short entertainments shown between feature films. Ironically, when the patchwork of human and animal humiliation and torture were stitched into a full-length feature film, the studio linked scenes together by pitching Wynant Hubbard as an ethologist. As a post-script, Hubbard eventually went bankrupt, and few, if any, of the animals he captured on or off-screen made it to a prospective zoo in one piece. Quoting Bender: "Wynant, fully aware of the precariousness of his own marriage and finances, craved affirmation of his hunting skill. Grasping at straws, if he couldn't bring animals back alive, at least he could face down - and kill—Africa's biggest beasts."16

Untamed Africa offers a perfect illustration of hubris and desire gone wrong. It is a key narrative for the Anthropocene. As I stripped back some of the more picturesque scenes I imagined how it might feel to be an ancient ancestor watching these enigmatic beings from across the savannah. In the visual distillate emerging from the purloined footage, I found myself transfixed by the coordinated movements of majestic animals in the distance and imagined a primitive desire to capture and hold onto something of their magnificence.

\section{OBJET (PETIT) A}

Similar to the endless interpretations of the meanings behind prehistoric cave art, there also seem to be innumerable variations on an idea central to Jacques Lacan's theory of desire, the "objet (petit) a". ${ }^{17}$ From time to time, during Lacan's weekly seminars, initiated in Paris in 1951, he would return to this idea in order to briefly circle around it once again. Perhaps as his final object lesson, he promised a book on the subject — which never appeared.

The "objet (petit) a" seems to move as a shifter around the object of human desire. Sometimes it is described as the thing that obscures or impedes the desired prize, sometimes it is described as the lesser prize that fills a need but not the desire. Other explanations oppose that idea and relate it to the "agalma", a magical prize of surplus enjoyment, imagined to be hiding within the object of desire, with the object of desire always providing a gap for it to hide within. It is with this latter interpretation that I will continue; we can't ever get what we want because our longing will always target exactly what we cannot have. The obscure object of our desire must always remain beyond our reach — because our want is, by definition, unanswerable.

To explain this idea, the wholeness we experienced as an easy rider in the womb is suddenly and unexpectedly ripped away from us at birth. This loss, the castration experience behind the anxiety, is profound, ongoing, and unresolvable. We were warm and comfortable, weightless, didn't have to find food or even breathe for ourselves. This is every single human's paradise lost and we will want it back for our entire lives. Loss becomes lack as the rip-cord is pulled and the engine starts up with a splutter and a wail.

The engine of lack runs on our desire for the "objet (petit) a". ${ }^{8}$ If we are lucky enough to be breastfed, we locate it in the breast, which always gives out or is taken away. From then on we manage to locate it elsewhere, but if ever we do manage to find some way to grasp the object that we believe encompasses the "agalma", we find it missing; the former object of our desire turns to dust in our hands. It never succeeds in making us whole because, of course, nothing can. We must immediately replace it with another, located in the distance, in order to live with our lingering deficit. We may answer our needs but we can never truly answer our want.

Instinctively, though not intentionally, the highly refined Hollywood structure of cinematic narrative clearly illustrates the Lacanian engine. A world in balance (life in the womb) is suddenly thrown out of kilter by a new crisis (birth), 
and a collision of forces ensues (being-in-the-world). At the end, the best part of the fantasy treat, satisfaction, the world finds a new balance. - Only in real life this can never happen (I can't git no... ${ }^{19}$ ), or at least not for long.

Humans diagrammatically described through this lens might appear as a double torus: one driven by a constant biological need to obtain energy through digesting other life forms, in tandem with the other, driven by a persistent psychological and emotional need to regain what has been forever lost in the form of an obscure object of desire. Between them, these engines of lack propel humans graspingly forward, chasing all around this small planet, as we try and we try, and we try, and we try, but we can't fill either empty middle for very long, if at all.

The "objet (petit) a" is the insatiable hunger that is at the heart of commodity fetishism and I would argue that this same dynamic would have once described our universal lust for the majestic megafauna that in most corners of the planet are now only marks on the walls of deep caves. Those magnificent animals, seen in the distance, excite a desire for their power and their beauty. But when we finally succeed in cornering them, they want less than nothing to do with our senseless desires.

\section{MAKING CONNECTIONS}

We have a few options for connecting with wild animals: we can paint them, carve them, fetishise them, dance with them, or dress up like them. Those efforts failing, we can eat them. We want the animals, but all we can really do is to bring them to ground, cage them, gaze at them, and murder them either quickly or slowly. We can have them analytically through methods of scientific study: vivisection, dissection or, if you have a weird sense of humour, through taxidermy. Behaviourally, we can get closer by kidnapping and imprinting their babies to follow us around, thereby damning them to dead-end human margins.

Maybe we are just hard-wired to love animals to extinction. On the one hand, our love is fervent, confused, impulsive and violent. Like Steinbeck's character of Lenny in the novella, Of Mice and Men ${ }^{20}$, we can inadvertently crush the objects of our affection. On the other hand, wild animals balk at our desire to know them, and our love can go bad when it meets with frustration; a radical reversal often seen when intimate relationships between humans fail.

Dramatic interactions, like those listed above, are the very meat of the cinema — an apparatus built upon our fascination for animals and our desire to know them better. In my art practice, the processes of disarticulated cinema enable me to model complex dynamics using methods of fragmentation and partial occlusion. In making artworks as propositional and epistemic objects, I recombine and redistribute cinematic elements in ways that activate my thinking about and around our Anthropocene predicament.

Aristotle's description of the soul in De Anima sought to define the ineffable enabler of embodiment that we share with virtually all multicellular organisms. We now know that every soul-bearing being he described nearly 2400 years ago, in turn owes their own internal biological alliances to ancient relationships forged between vast arrays of microbes operating in concert and opposition with each other, and with every unique environment they tumbled into.

Setting the stage for the Enlightenment, dualism gave license to both rationally and magically transform all plants, animals, and othered peoples, into soulless biological machines. By bringing the concept of a detachable soul, and assigning it exclusively to certain humans, Descartes rendered all the othered animals and organisms as disposable biomechanical devices; objects devoid of rights, here to serve or to burn in the hope of quenching our insatiable desires. In embracing this pernicious idea we have permitted ourselves to slash the plexiform web of intricate connections, including those of our forbearers and of our nearest relations, renting the very fabric of our own existence.

In this article I investigated some of the questions, thoughts, and digressions prompted by disarticulating an animal exploitation film from the early years of the twentieth century. I have considered the complex, and seemingly insatiable, nature of human desire and its role in the environmental collapse that we see playing out before us. The 
world has changed a lot over the last 90 years; we share so much more of it with other humans and so much less of it with other species. Bullets, nets, bulldozers, and plows continue to claim more of the finite and delicate web of life our sub-species was born into.

Recently, the global transmission of Covid-19 found many of us temporarily contained in self-isolation across the world. For a moment in time the fires of commerce slowed down. Almost immediately a dramatic drop in toxic emissions from vehicles and industries was registered by satellite over some of the most polluted regions on earth. Soon images of wild animals reclaiming territory long since held by humans and their machines flashed across the internet. Even in New Zealand, indigenous birds ventured from their margins in the hope that we had finally departed. As I write this we are in the early days of recovery from our first round with the deadly virus, and so far the overwhelming response to a timely opportunity to reconsider our ways - is simply to make up for lost time.

David Green is an artist who lectures at the Dunedin School of Art. He is interested in applying the phenomenology and the neurology of perception to the collaborative engagement between artwork and viewer.

I George Bataille, Theory of Religion. Trans: Robert Hurley (New York: Zone Books, 1989), 35.

2 Eric R. Kandel, The Age of Insight:The Quest to Understand the Unconscious in Art, Mind, and Brain, from Vienna 1900 to the Present (New York:The Random House Publishing Group, 20 I2), 333.

3 David Green, "Emergence," Scope: Contemporary Research Topics 13 Art and Design, (2017): 30-37.

4 Semir Zeki, “Parallel Processing, Asynchronous Perception, and a Distributed System of Consciousness in Vision," Neuroscientist 4, no. 5 (1998): 365-372.

5 Exaptation is a feature of evolutionary adaptation that takes a sudden leap to perform a second completely unrelated but equally adaptive function: for instance, feathers were thought to have been originally selected for their insulation value, but one day afforded escape from a predator through an accidental flight, becoming adaptive in a secondary, unrelated, and emergent way. Stephen Jay Gould, Elisabeth S Vrba, "Exaptation - A Missing Term in the Science of Form," Paleobiology, 8, No. I (Winter, 1982): 4-15.

6 Mark Shiffman, Aristotle De Anima (Newburyport: Focus Publishing, 201 I), 53-61.

7 Werner Herzog, dir., Cave of Forgotten Dreams, Creative Differences (2010).

8 Screenshot of Cave of Forgotten Dreams. https://commons.wikimedia.org/wiki/File:Rhinos_Chauvet_Cave.jpg, Public Domain.

9 "....in contrast to the reversibility of figure and ground within the discontinuous world, the figuration of the discontinuous human world against the ground of the continuous pre-human world is irreversible." Kevin Fisher, "The Ecstatic Gestalt in Werner Herzog's Cave of Forgotten Dreams," Refractory: A Journal of Entertainment Media, 24 (20।4): 6

10 John Berger, About Looking (New York:Vintage Books, 1980), 6-7.

I I Jonathan Burt, Animals in Film (London: Reaktion Books Ltd, 2002).

12 Ibid, 50-52.

13 lbid, 65-69.

14 De Leon Anthony (writer), Untamed Africa, Warner Bros. (1933).

15 Daniel Bender, The Animal Game (Cambridge: Harvard University Press, 2016), 85-88.

16 Ibid, 85-88. 
17 Jacques Lacan and Jeffrey Mehlman, "Introduction to the Names-of-the-Father Seminar," October 40 Television (Spring, 1987$): 82$

18 Jeanne Lorraine Schroeder, The Four Lacanian Discourses: OrTurning Law Inside Out (Oxford: Birbeck Law Press, 2008), I 8-2 I.

19 Although I don't roll with his precise interpretation, Professor Paul H. Fry rocks when making use of the Rolling Stones' song Satisfaction (1965) to illustrate the idea of Lacan's "objet (petit) a" in his Yale Open Course, Introduction to Theory of Literature, entitled "Jacques Lacan in Theory."

20 John Steinbeck, Of Mice and Men, (United States: Covici Friede, 1937). 